
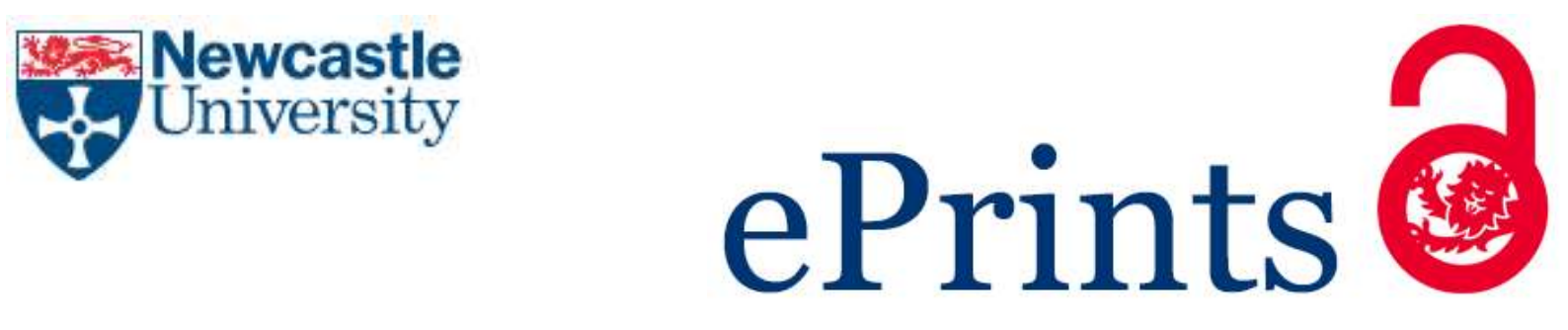

Parola F, Ferrari C, Tei A, Satta G, Musso M. Dealing with multi-scalar embeddedness and institutional divergence: Evidence from the renovation of Italian port governance. Research in Transportation Business \& Management 2017

Copyright:

(C) 2017. This manuscript version is made available under the CC-BY-NC-ND 4.0 license

DOI link to article:

http://dx.doi.org/10.1016/j.rtbm.2016.12.005

Date deposited:

$13 / 01 / 2017$

Embargo release date:

03 January 2018

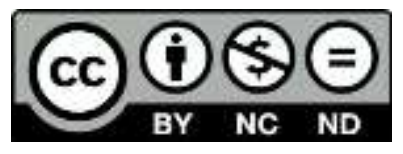

This work is licensed under a

Creative Commons Attribution-NonCommercial-NoDerivatives 4.0 International licence 


\title{
Dealing with multi-scalar embeddedness and institutional divergence: evidence from the renovation of Italian port governance
}

Francesco Parola ${ }^{1}$, University of Genoa (Italy), Department of Economics and Business, parola@economia.unige.it

Claudio Ferrari, University of Genoa (Italy), Department of Economics and Business, ferrari@economia.unige.it

Alessio Tei, Newcastle University (UK), School of Marine Science and Technology,

alessio.tei@ncl.ac.uk

Giovanni Satta, University of Genoa (Italy), Department of Economics and Business, giovanni.satta@economia.unige.it

Enrico Musso, University of Genoa (Italy), Department of Economics and Business, enrico.musso@economia.unige.it

\begin{abstract}
Conventional studies on port governance reform mostly propose de-contextualized models, which overlook the embeddedness forces of ports in specific institutional and economic domains. To overtake such a gap, this paper challenges traditional models and proposes an alternative contextualization of governance schemes in local territorial contexts. Therefore, the manuscript analyzes institutional trajectories in port governance, by advancing knowledge on the risks of the reform processes implemented in rigid institutional frameworks, reluctant to conjugate global challenges with local claims. Institutional divergence may emerge between the objectives set at governmental level and the claims at regional / port level, by causing a delay of the implementation stage. For this purpose, the study addresses the Italian port context, as a meaningful empirical case. The paper adopts an original theoretical frame, by encapsulating the well-established notions of intended and emergent strategy within the construct of institutional plasticity applied to public organizations. The outcome of the Italian case unveils that the ongoing reform process is still partially inadequate to capture some urgent requirements as expressed several times by different port communities and stakeholders. The lack of a bottom-up perspective and local adaptation may constitute a dangerous drawback of the new governance framework.
\end{abstract}

Keyword: port reform, Italy, embeddedness, plasticity, institutional divergence.

${ }^{1}$ Corresponding author 


\section{Introduction}

The ongoing port governance reform taking place worldwide has attracted the attention of both academics and practitioners (Brooks, 2007; Ng and Pallis, 2010), in the attempt to identify the most suitable and viable options for restructuring the industry. In particular, port devolution represents a central paradigm in the redesign of port institutional framework in a number of countries (Sánchez and Wilmsmeier, 2006; Brooks and Pallis, 2008). Nonetheless, conventional studies tend to outline de-contextualized models, which ignore the embeddedness forces of ports in specific institutional and economic domains (Olivier and Slack, 2006).

In order to overtake this gap, this paper challenges traditional models of port governance reform, and calls for a deeper contextualization of governance schemes in local territorial contexts. In particular, the manuscript analyzes the institutional trajectory of the Italian port governance, disentangling the effects of a process of (re-)centralization of executive decisions and strategic choices related to ports. The study aims to advance knowledge on the effects associated to port reform processes that could results in rigid institutional frameworks (sometimes resulting mainly from current or prevailing political trends), reluctant to conjugate global challenges with local claims. This constitutes a significant research gap in port management literature that deserves an ad hoc investigation.

The Italian port case, indeed, does represent a sound empirical field for achieving a deeper understanding of the impact of multi-scalar embeddedness that originates at both national and local level. In particular, at a regional scale, various territorial forces offer powerful institutional and lobbying inputs that shape the trajectories of reform in individual ports. In this perspective, Italy brings special legislative and governance challenges for policy makers and regulators, given the strong negotiating power held by local port stakeholders such as terminal operators, concessionaires, ship agents, freight forwarders, and unions (Debrie et al., 2013; Notteboom et al., 2015).

In addition, the timeframe of the investigation is consistent with the aim of the study, as during an ongoing port reform process institutional fluidity increases. Both national (governmental) and local institutional actors and political forces proactively interact and compete in order to reach their respective strategic objectives.

In our study, the issue of multi-scalar embeddedness in the Italian port reform process (as stated by the legislative decree no. 169/2016) is addressed, by combining two well-established theoretical constructs: i) institutional plasticity; ii) intended versus emergent strategy. For this purpose, we first introduce the concept of 'institutional plasticity' (Strambach, 2010) to emphasize how port actors strategically stretch existing institutional arrangements to their purpose, without (necessarily) breaking out the dominant development path. Then, we encapsulate the well-established notions of intended and emergent strategy (Ansoff, 1965; Mintzberg and Waters, 1985) within the institutional plasticity construct in public organizations, such as the Italian Port Authorities (from now on PAs), in order to disentangle the multifaceted nature of institutional turns.

This original theoretical framing enables to treat port governance changes as a complex evolutionary process as well as to differentiate between the actual policies that are implemented in 
practice (realized reform), from policies intended by the legislator (intended reform). In plastic institutional environments, port governance changes are expected to follow an iterative evolutionary process that conjugates the "intended" reform conceived by central government with a number of "emerging" reform claims that are expression of local stakeholder interests. Throughout plasticity, in fact, some governance reform changes imposed by global challenges can be locally adapted in each port domain.

In those maritime countries, like Italy, that are characterized by heterogeneous socio-cultural backgrounds and are exposed to multi-directional embeddedness forces at local level, a reform process should pursue a hybridization of governance models in order to create a differentiated institutional puzzle (Debrie et al., 2013). The lack of plasticity and adaptation capability might drive to progressive institutional rifts between local and governmental institutions during both the approval and the implementation phases of the governance reform.

The paper is structured as follows. Section 2 sets the theoretical framework by combining the constructs of institutional plasticity with the notions of intended versus emergent reform. Section 3 depicts the Italian empirical context, by describing the outcome of the 1994 reform law and the (failed) attempts to revise the law. Section 4 unveils the contents of the Reform recently approved (August 2016). Further, Section 5 tries to identify the potential drawbacks of the reform, originating from institutional divergence between centripetal and centrifugal forces. Finally, Section 6 brings some concluding remarks.

\section{Reframing port governance: multi-scalar embeddedness and need for institutional plasticity}

Over the last years, academic literature recognized the growing heterogeneity of landlord models in various market contexts, translating into differentiated organizational, managerial and ownership models. In business practice, indeed, landlord paradigm needs a reconfiguration and adaptation to local constraints and historical background that often trigger towards a hybridization of the traditional models identified by the World Bank (2007). These growing institutional needs are addressed in academic contributions that emphasize the effectiveness of institutional plasticity's mechanisms for mediating between local (centripetal) and global (centrifugal) forces (Notteboom el al., 2013).

In this section, we posit the issue of the impact of multi-scalar embeddedness in an institutional framework under reform characterized by an ancient maritime tradition and a strong entrepreneurial fabric in port logistics. Indeed, institutional plasticity is expected to trigger adaptive processes on a local scale in order to keep the pace of market transformations and to be proactive respect to evolving needs of stakeholders.

\subsection{Multi-scalar embeddedness and territorial forces}


Transport economists commonly recognize the role that path dependence plays in shaping local and national differences in port governance structures and reform trajectories (Notteboom et al., 2013). Indeed, the notion of path dependence derives from the evolutionary approach, which is appropriate to analyze the evolution of organizational bodies such as PAs (Hall and Jacobs, 2010). Despite the existence of macro-trends of reforms that sketch some well-established global directions in port governance mechanisms, a growing number of scholars (Hall, 2003; Ng and Pallis, 2010) refuse the postulate of geographic convergence in port reform dynamics, but rather commit to complex hybridization of models in each territorial domain (Fremont and Lavaud-Letilleul, 2009; Debrie et al., 2013). Therefore, the construct of path dependence is weakening its explanatory power given the differentiated character of public policy sectors and the heterogeneous social, cultural and economic trends that materialize at different regional scales (Dobry, 2000).

Some studies have offered a pragmatic understanding of port governance by looking for empirical evidence in order to explain specific port governance arrangements, often resorting to the notion of embeddedness as a key analytical lens. This concept, coined by Granovetter (1985), incorporates the idea of an essential societal contextualization of economic processes, and entails multilevel spatial scales as well as local dimensions (Hess, 2004). In the port context, Notteboom et al. (2013) recognized that PAs are place-dependent, as these institutions remain specific to certain territories. They are "embedded within spatially proximate social relations and developed under unique historical trajectories and contingencies, so that there remains ample scope for variation" (Gertler, 2001). This means that international port reform patterns have to deal with various sources of embeddedness at a national and regional scale, including economic dependence on natural resources, sunk costs of assets and infrastructure, and agglomeration externalities that fuel industrial clusters (Storper, 1997; Martin and Sunley, 2006). Multi-scalar embeddedness forces may also derive from regulatory frameworks, social conventions and cultural traditions, which can lockin firms and public organizations in the social and institutional specificities of a country or a region (Granovetter, 1985; Martin and Sunley, 2006). Therefore, the effects provoked by path dependence on ports are shaped in different ways across various places and territorial scales (Notteboom et al., 2013).

The theoretical construct of multi-scalar embeddedness brings insights for a flexible and dynamic reading of port governance mechanisms and enables a deeper understanding of territorial trajectories of reform by country and by port. In this regard, prior studies provide empirical evidence of the idiosyncratic nature of national reform patterns, unveiling lock-in effects and territorial variations in the process of port governance restructuring (Wang et al., 2004, p. 238; Ng and Pallis, 2010). In particular, Debrie et al. (2013) recognize that the combined effect of global trends and local specificities in the evolution of governance models drives to the emergence of territorial trajectories of reform at various scales. This is provoked by local reactions (e.g., concession policies, labor issues, etc.) to national and global changes that can be categorized in relation to the effects generated by such (global-local) interactions on port governance. In particular, the taxonomy proposed by Debrie et al. (2013) outlines: i) path follower ports, where local forces are weak and the implementation of national changes is fairly easy, ii) path adaptor ports, where local forces impose a local adjustment on the national framework, iii) path resistant ports, where local inertia 
and lock-in effects provoke frictions and conflicts, and thwart or slow down the implementation of national reforms, and iv) path leader/pioneer ports that are triggered by local forces to generate innovative solutions in port governance, project funding, marketing and inter-port coordination, thus reaching beyond national reform changes and/or anticipating innovative trends. Path follower and path adaptor ports are expression of a top-down process that leads to institutional convergence in port governance settings, whereas path resistant and path leader ports originate from a bottomup process, leading to some forms of institutional divergence.

\subsection{Need for "plasticity": intended versus emergent reform}

Academics in the field of port management have started to reconsider the deterministic perspective on lock-in effects and applied the notion of institutional plasticity to port governance settings and PAs (Notteboom et al., 2013), following the approach undertaken by economic geographers in advancing the theorization of public institutions (Strambach, 2010). Institutional plasticity is the outcome of actions of various stakeholders to suitably "recombine and convert or reinterpret institutions for their new objectives or transfer institutions to different contexts" (Strambach, 2010). The construct of plasticity has been reinforced by the growing criticisms related to the predominantly negative connotation of lock-in (Martin and Sunley, 2006). In recent years, in fact, scholars shifted their attention from path dependence to path destruction and path creation, also emphasizing the positive and proactive role potentially played by local forces in reframing institutional frameworks (also triggering in de-locking effects) and centrally-driven reform processes (MacKinnon et al., 2009; Strambach, 2010).

The term "institutional plasticity" refers to a situation where an array of (alternative) development trajectories are possible within the whole institutional framework, without necessarily disrupting the extant path. Plasticity evokes a fluid stretch of institutions and organizational settings through deliberate action and flexible interpretation of the existing legislative framework. In addition, plasticity also means to smoothly (re-)shape rules and extant institutional mechanisms to the specific needs expressed by the stakeholders community in various local contexts. Indeed, institutional transformations can be implemented along diverse modes. First, institutional stretching materializes when actors modify existing arrangements. As such, "institutional plasticity" is a descriptor for flexibility "within" and "among" public institutions, as they may both induce transformations by players and, in turn, are themselves modified over time by actors' actions (Notteboom et al., 2013). These dynamics take place under stable legislative frameworks (interreform periods), when actors try to compensate weaknesses and lacks of the existing legislative framework by adopting "palliative" institutional measures and other unconventional (and informal) actions. Indeed, this can be depicted as a never-ending institutional "fine tuning", enabling public organizations to keep the pace of stakeholder needs.

Conversely, in case of formal variation of the institutional and legislative framework, we may have "layering" or "conversion" actions. Layering is constituted by the progressive introduction of new rules or procedures in extant institutions or by the addition of new functions to current institutional arrangements (Martin, 2010). Each new "layer" produces only a small modification of the entire 
institution but, as the process can be cumulative, that evolution can ultimately lead to formalized and substantial institutional transformations (Martin, 2010). Finally, conversion is the alteration of existing institutions to serve new purposes or functions. In some circumstances, the introduction of a new layer might imply abandoning prior layers, while conversion does not contemplate new rules but the realignment of existing institutions and arrangements (Notteboom et al., 2013). Indeed, reform time windows constitute an ideal opportunity for pursuing a "fluid" reconfiguration of governance mechanisms at various institutional scales. When the reform debate is ongoing, in fact, there is a much wider room for undertaking layering and/or conversion paths by regulators, PAs and other institutions. In other words, a reform process enhances the plasticity of the institutional framework and stimulates the dialogue between local and central institutions heading towards reform objectives by means of accurate roadmaps.

In those maritime countries that are characterized by heterogeneous socio-cultural backgrounds and are exposed to multi-directional embeddedness forces at local level, a reform process should pursue a hybridization of governance models in order to create a differentiated institutional puzzle. The reform process, indeed, has to take into account path dependence drives at global scale while mediating between multi-scalar embeddedness forces at country level. In addition, in presence of fragmented and diversified local backgrounds regulators and policy makers need to capture various territorial claims and to encapsulate them in a balanced overarching institutional design.

Institutional plasticity is therefore important for managing complex reform patterns where the central government is the process leader and local forces generate strong bottom-up pressure that entails path destruction or path creation and related 'de-locking' processes (Notteboom et al., 2013). In plastic institutional environments, port governance changes are expected to follow an iterative evolutionary process that conjugates the "intended" reform conceived by central government with a number of "emerging" reform claims that are expression of local stakeholder interests. In this regard, the application of the well-known managerial theoretical constructs of Ansoff (1965) and Mintzberg and Waters (1985) (i.e. intended versus emerging corporate strategy in private firms) to the notion of institutional plasticity in public organizations, such as PAs, enables to disentangle the multifaceted nature of institutional turns. Port governance changes, therefore, differentiate between the actual policies that are implemented in practice (realized reform), from the policies that were intended by the legislator (intended reform). In fact, territorial trajectories of reform often imply local reactions (emerging reform claims) to national and global changes. The realized reform is the result of a process of negotiation, and often compromise, between deliberate (top-down) and emerging (bottom-up) factors. Thus, as argued by Debrie et al. (2013), the realized reform may be only partly related to initial design that was intended by the legislator. In this vein, $\mathrm{Ng}$ and Pallis (2010) empirically recognize the complexity of the overall port governance reform process, unveiling how decision makers have to implement general solutions in specific territorial contexts, managing the transition from pre-reform settings to post reform conditions.

\section{Empirical context: the Italian port governance case}


The case of the Italian port governance constitutes a fertile empirical ground for achieving a deeper understanding of the effects produced by multi-scalar embeddedness that originates at both national and local level. At a regional scale, various territorial forces offer powerful institutional and lobbying inputs that shape the trajectories of reform in each port. In this regard, Italy raises special legislative and governance challenges for policy makers and regulators, given the strong negotiating power held by local port stakeholders such as terminal operators, concessionaires, ship agents, freight forwarders, and unions (Debrie et al., 2013; Notteboom et al., 2015), as well as, on the other hand, the worldwide known and almost proverbial complexity and instability of political action at all governmental levels.

\subsection{The 1994 reform: a controversial outcome}

Extant Italian port governance settings paves on the port reform law no. 84, approved in 1994, that introduced the landlord model. Since then, planning and monitoring activities continued to be in the hands of a public authority (i.e. the Port Authority), whereas terminal management and commercial operations have been left to private firms (e.g. Valleri et al., 2006). That law established 18 PAs that replaced former public entities managing ports. The reform, indeed, has also dramatically affected port labor, by eliminating the market reserve of dockworker pools, and allowing private firms to organize and manage terminals through authorizations and administrative concession acts. Ever since, the role of the public sector has been relegated to the strategic planning, through the adoption of both port master plan and three-year operating plan (TOP).

The full implementation of the reform really stimulated the "renaissance" of the national port system (Marchese et al., 1998). It favored the market entry of private terminal operators, triggered domestic and international investments and made the organization of port labor more efficient. As a result, in a few years, the container throughput of national port system grew from 2.6 million TEU in 1994 to 6.9 in 2000. Together with the booming of containerized commodities, the overall cargo handled by Italian ports grew significantly (over 10\% between 1997 and 2002), also showing some outperforming ports (e.g. the port of Genoa increased by over 20\% in the 1994-2000 timeframe).

Figure 1 reports the market share of main Italian ports compared with Mediterranean and European competitors. Two different stages clearly emerge, showing rather controversial outcomes. Initially, after the approval of the reform, Italian ports' market share grew up, reaching its peak at the end of the '90s. The new rules ensured a higher productivity, additional investments made by international terminal operators and the formation of skills and know-how. In particular, PSA acquired stakes (1998) in VTE (Genoa) and Vecon (Venice) terminals, while Eurokai became the main shareholder of the Contship Group, i.e., founder of the hub facility in Gioia Tauro.

Later on, after having accomplished the transition from the public to the landlord model, the newly established PAs were called to expand port areas by undertaking long-term investments and involving private concessionaires. The start of such phase of development unveiled some limits of the reform in terms of PA managerial mechanisms: unstable governance conditions (e.g., interim presidents, legal disputes, etc.), scarce financial autonomy and slowness in planning and 
construction administrative procedures. This second stage was much less effective than the previous one.

Hence, the bureaucratic vision embedded in the port reform emerged as a clear weakness in PA governance. PAs were not sufficiently proactive for coping with the ongoing challenges in the shipping and logistics sectors. Moreover, most port incomes were awarded to the State and then redistributed among PAs, regardless of port size and performance. This uneven mechanism caused significant financial concerns in a number of ports (Carbone and Munari, 2006).

From early-2000s some local port administrations were upgraded to the status of PA, thus increasing the total number of PAs up to 24. This provoked a further fragmentation of public transfers from the central government to the entire port system, weakening the resources for leading ports (Caballini et al., 2009). This was closely associated to excessively long timeframes for project implementation as well as to the lack of an overarching port vision at national level (Ferrari and Musso, 2011).

Figure 1 - Market share and growth rates of the Italian port system

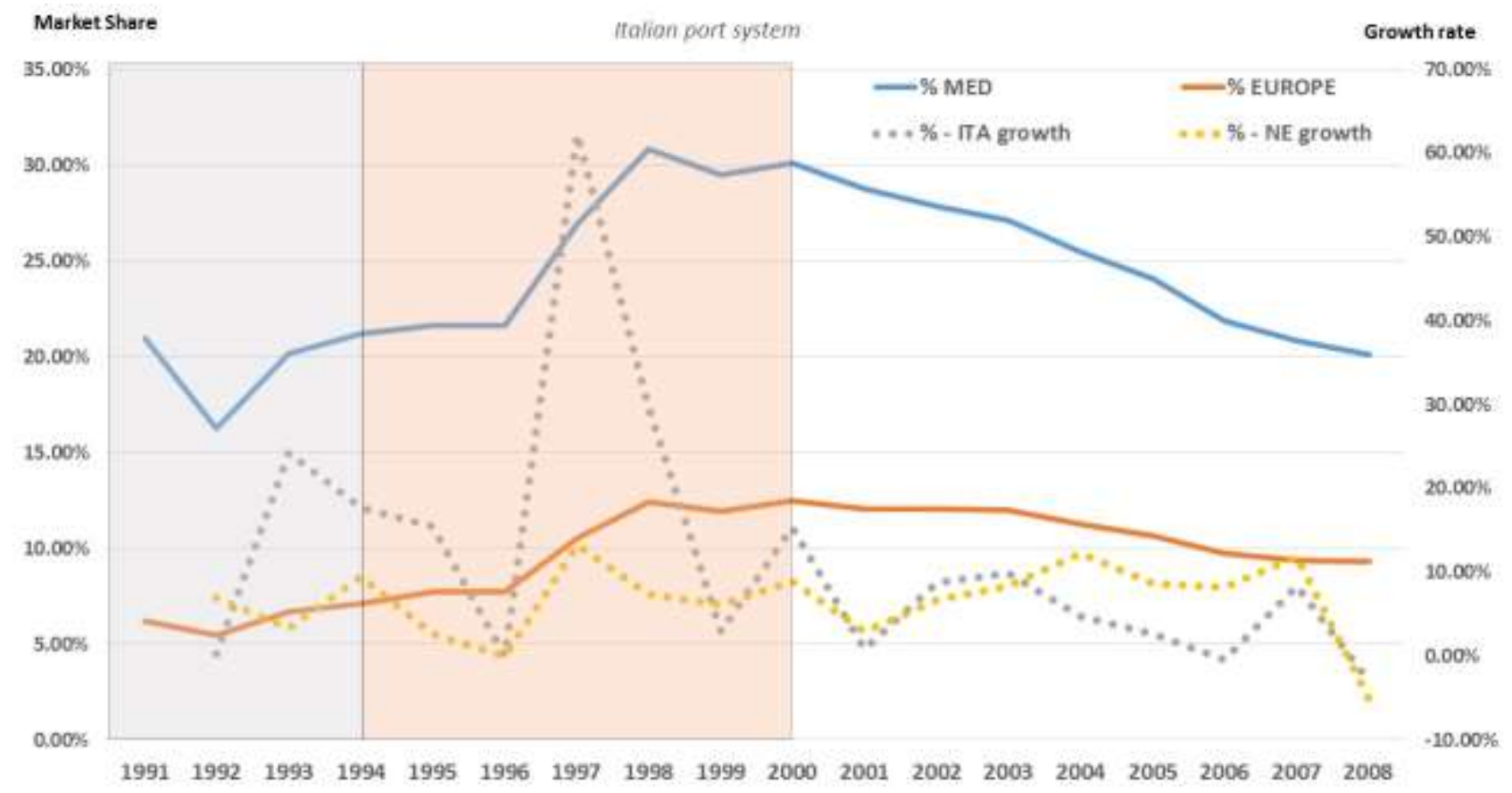

Source: authors' own elaboration from Containerisation International (2016 data).

To sum up, although the port reform played a key role in the modernization of the Italian port system, it failed to accommodate major stakeholders' claims (e.g. infrastructural endowment, inland terminals and dry ports, IT solutions, etc.). The reform, in fact, was predominantly focused on the maritime side, addressing issues such as the regulation of the functions of private investors, the utilization of terminal concessions, the search for an increase of nautical accessibility and shipto-shore performance, etc. while neglecting landside development. 


\subsection{Failed reform attempts}

From 2006 onwards, a number of reform drafts have been prepared for the Parliament discussion, in order to increase port performance and cope with some legislative gaps (e.g. Parola and Maugeri, 2013).

At the end of the '90s the Italian port system achieved its peak in terms of market share, handling about one third of Mediterranean container volumes. Afterwards, its market share suddenly started to decline, experiencing growth rates lower than major competitors. Relatedly, Figure 2 reports data on the container throughput.

Figure 2 - Growth rate of the main EU port regions.

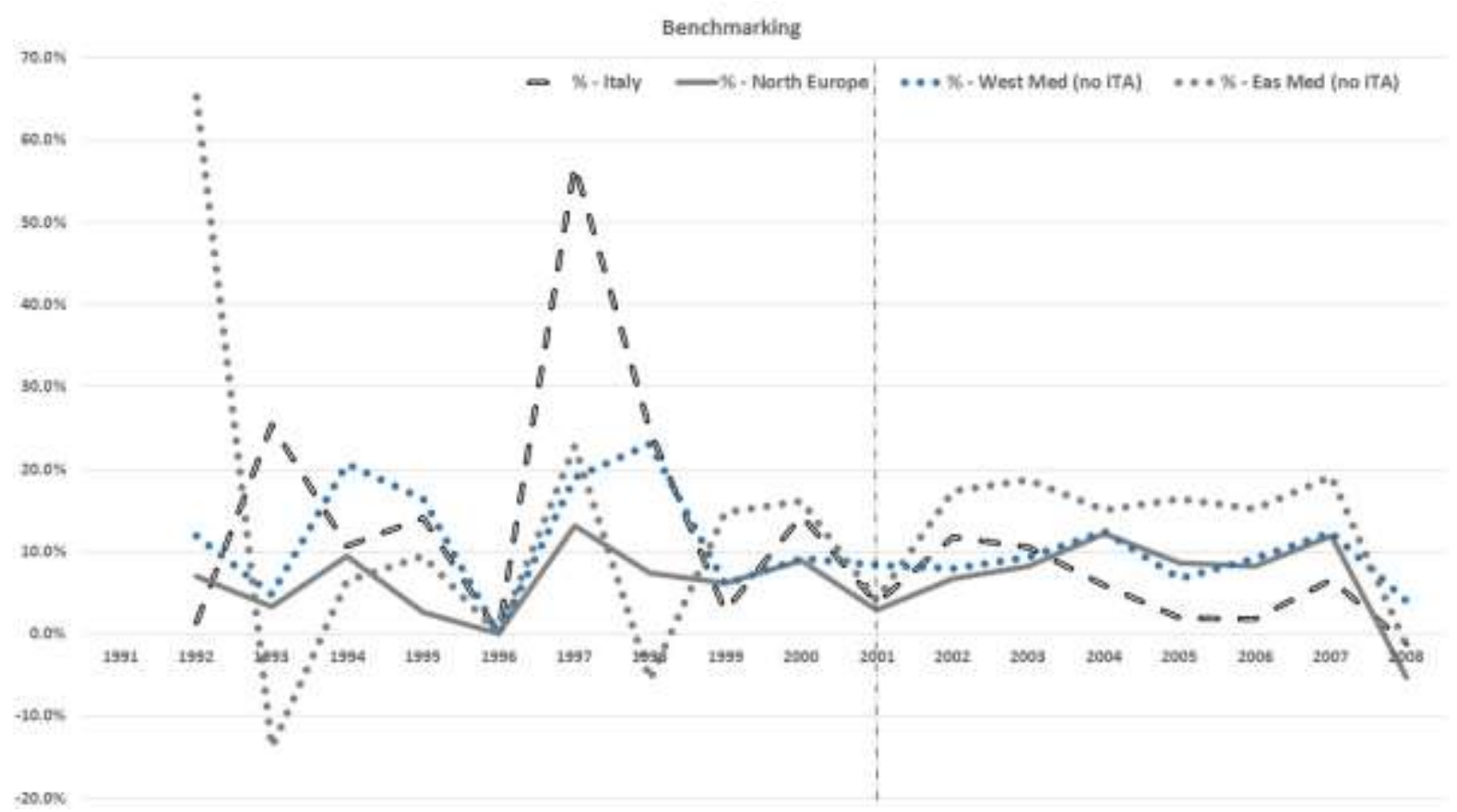

Source: authors' own elaboration from Containerisation International data, 2016.

Since 2003, in fact, the port throughput of all the European maritime regions (i.e. Northern Europe, East Med and West Med) registered growth rates higher than Italian ports. Countries like Spain, France, Greece and Croatia undertook a reform process and this boosted the competitiveness of their ports. In addition, the economic crisis struck the Italian port system more heavily than competitors. Although the first reform draft had been presented in 2006, already, a persistent political instability (three general elections and five different Cabinets from 2006 to 2014) coupled with a deep financial crisis drove to intensive modifications within the parliamentary discussion and, finally, undermined its final approval.

Despite several previous attempts, the port reform was included again in the political agenda only in 2014, introducing an ad hoc article within law n. 164/2014 (the investment law known as Sblocca 
Italia). That article established the creation of a special committee of experts having the goal to analyse current weaknesses of the Italian port systems, and to propose possible interventions. In May 2015, an official document was realised and by the following autumn, the first formal draft entered into the Parliament discussion. Until June 2016, no official conclusion has been reached. In the meantime, two third of the Italian PAs came under the control of government-appointed commissioners (interim presidents), i.e. administrators nominated by the government with no possibility of implementing "extraordinary" actions. The Italian government, in fact, decided to avoid ordinary procedures for appointing PAs' presidents, until the full implementation of the new port reform law. During the 10 years in between the first bill and the current discussion, several contributions (e.g. Musso and Ferrari, 2011; Parola et al., 2012; Consulta Nazionale per I'Autostrasporto e la Logistica, 2011; MIT, 2015) shed lights on those critical issues that the port reform was called to solve. Briefly, they can be categorized into four major categories: (i) planning limits under the current legislation; (ii) financial issues; (iii) spatial scale of PA intervention; and (iv) port service providers.

Planning limits under the current legis/ation (i) refers to the complexity of planning procedures within the port domain which drives to an increase both in the timing and the costs of political intervention and reduces responsiveness of public and private actors involved in port activities. The overall planning architecture determines systemic rigidities within the decision making process (Parola et al., 2012). This dramatically emerges when it comes to concession agreements lasting for over than 20 years. As the port industry experienced a number of shift in market and competitive trends during the last decade (e.g. increasing vessel size, vertical and horizontal integration, new role of North African ports, etc.), the aforementioned rigidity makes the Italian port system vulnerable. For this purpose, several solutions have been proposed, including decentralisation and PA corporatization (e.g. Everett and Robinson, 2007; De Langen and Heij, 2014). These approaches, typically, aims to define more flexible planning process within the port domain, where concessions are substituted by agreements more similar to renting contracts, and where PAs gains a pro-active role in the port operation and port investment strategies. Nevertheless, the document draft currently under discussion addresses these issues only partially - as argued by the port companies associations - since the PA is expected to remain a pure "planning and regulatory body", and the use of state owned land (and sea) is strongly interconnected to the environmental issue, which remains prior to public-private economic regulations. However, the new legal framework reduces the number of actors involved in the port committee, as well as its executive competences.

As concerns financial issues (ii), although the port reform was initially able to attract local and foreign private investments in the port sector, since 2000s other Mediterranean port systems (e.g., Spain, Greece, Morocco and Egypt) provided higher profitable investment opportunities. The lack of financial autonomy, which characterized the Italian PAs, made the profitability of port investments dependent from the public funding decided by the central government. The fuzzy amount of public transfers awarded to each port - often dependent more on political logrolling than on an assessment of net public benefits - made projects less attractive for private investors. The centralized financial resources allocation process, in addition, did not reward efficiency, effectiveness, and the dissemination of best practices. Additional public investments became 
difficult to be settled thus lowering the competitiveness of Italian ports respect to other EU ports. Although financial autonomy has been recognized as the main claims of the Italian Seaport Association (Assoporti), the draft under discussion neglects this issue.

Coming to the spatial scale of PA intervention (iii), the law n. 84/1994 established that PAs should only plan and regulate activities within the port borders, without any possibility to overtake them. This legal framework appear dated, as nowadays ports are no longer independent nodes within the transport network but they are embedded in international transport networks and their success depends upon their role in fostering the competitive performance of the logistics chain as a whole (van der Lugt et al., 2013). Moreover, the high number of PAs and the relative small size of the port facilities managed by each of them, coupled with the aforementioned centralized re-allocation of the financial resources, fragmented port investments and prevented PAs to reach sufficient economies of scale for serving wider hinterlands. The limits established by the port law are in contrast with ongoing trends. In this perspective, in fact, leading PAs have paved a number of innovative strategic avenues, including (Parola et al., 2013) the role of facilitator (de Langen, 2004a, 2004b), the commitment in hinterland development (Van den Berg and de Langen, 2011), "cooperative strategy" at various scales (Slack et al., 2009) and internationalization strategy (Verhoeven, 2010; Dooms et al., 2013).

This new role of the PAs - discussed in Notteboom and Rodrigue (2008) - was often under discussion in several port reform proposals with the possibility to introduce Logistics Authorities able to intervene in wider regions and to coordinate several PAs (e.g. Ferrari et al. 2015a; 2015b). Nevertheless, the current draft introduces new Port System Authorities aiming at coordinating and aggregating - several PAs but with no explicit role outside the administrated port(s).

Finally, concerning port service providers (iv), during the last decade Italian ports experienced the monopolistic provision of both marine (e.g. mooring and piloting) and peak-time labour pool services. The rationale of this organisation is predominantly related to safety and service quality issues. Several PAs and private companies (e.g. Costa and Casagrande, 2011) claimed that the current structure determines unjustified high port costs compared with other EU ports, arguing that both in-house self-produced services by private operators and the introduction of competitive markets are viable solutions, at least in main ports. Several Spanish and Northern ports have trod along this path for nautical port services, but not always achieving successful results. The extant draft of the reform ignored these claims. Only some attempts to incentivize competitive public bids for reducing the bargaining power of local marine service providers and to improve tariff methods (currently tariffs rely on the "Internal Rate of Return" rule instead of the "Price Cap" method) have been discussed. Conversely, labour pools' rules are not expected to be changed.

\section{The approved reform process}

Despite of the aforementioned pressures exerted by various sectorial lobbies, the final port reform - the legislative decree nr. 169 approved on 4th August 2016 - does not catch with several requests from relevant port stakeholders. In addition, also the decisional process leading to the new port reform appears somewhat fuzzy and heterodox (see Figure 3). 
The new legal framework originates from an article included within the above mentioned investment law n. 164/2014, which aims to reform the Italian port system, paving on the first "National Strategic Plan for Ports and Logistics Systems". The government further developed the plan through a two-step process. First, an ad hoc Committee of Experts designated by the Italian Ministry of Transport relied on prior governmental pioneering studies in order to assess the extant situation of the Italian port system. Then, the aforementioned ministry further elaborated those studies to update the National Strategic Plan and to introduce a call for the new port reform.

In 2015, within a formal document focused on the national port system, i.e. "Studying Initiative on the Italian port system", the Presidency of the Council of Ministers pointed out the major weaknesses threatening Italian ports: sub-optimal ports' size; insufficient financial resources and funding source; low competitiveness within the international arena; inefficiencies related to hinterland connections. Despite this, in the same document positive forecasts on national port traffic and system evolution were reported for the next future.

Figure 3. The political process leading to the definition of the new governance framework.

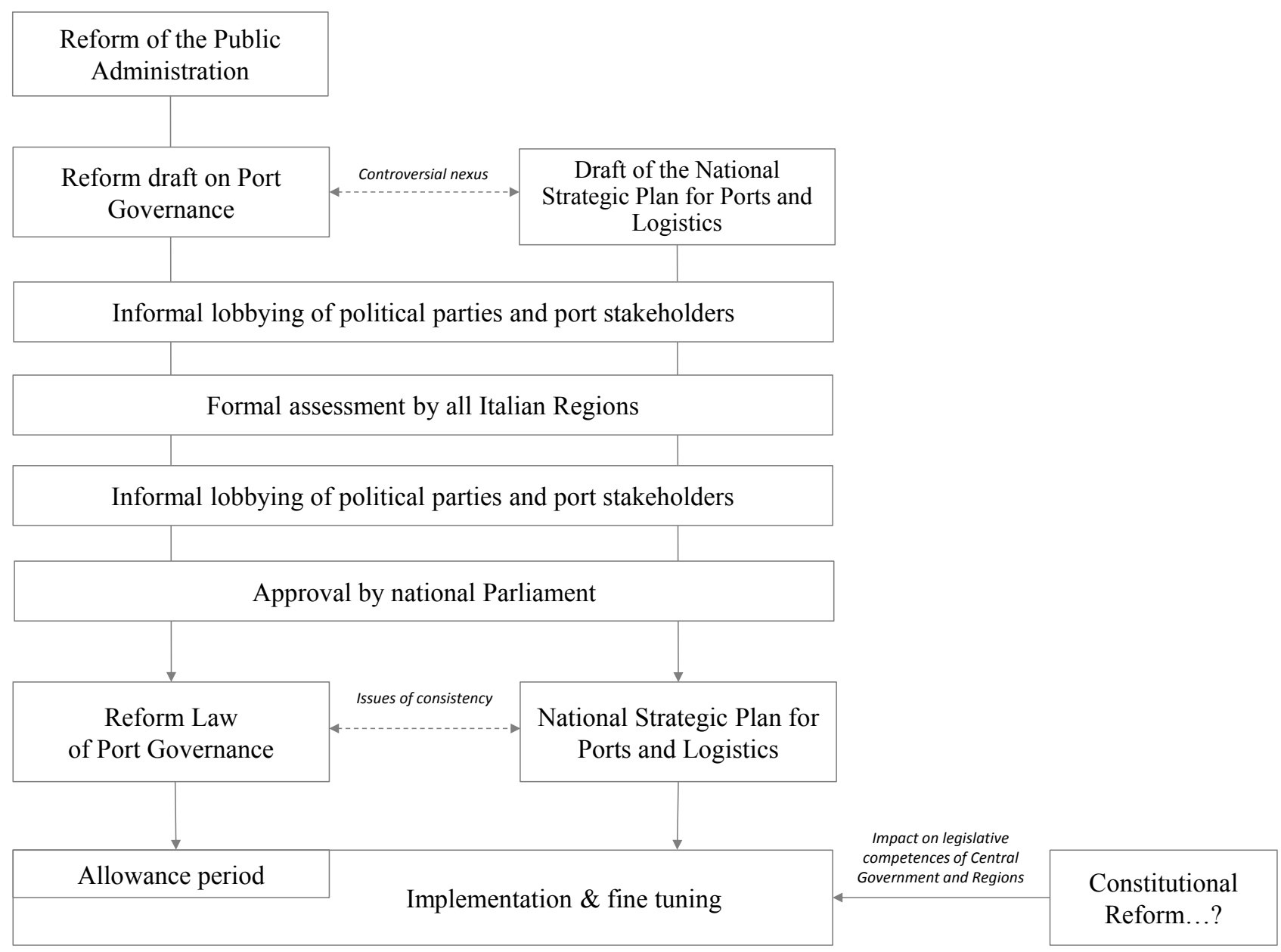

Source: authors' own elaboration. 
Grounding on this document, in the late spring 2015, the Committee of Experts charged for interviewing relevant port stakeholders and gathering their opinions on Italian ports performance, released a final report, which influenced the ongoing political discussion on port reform. In fact, it constituted the pillar for the updating of the National Strategic Plan for the Ports and Logistics Systems, reported by the Italian Ministry of Transport, in July 2015.

In the updated version of the Plan, ten priority objectives, to be achieved through port reform and additional suggestions, were set. In particular, in accordance with the outcomes of the Plan, the previous 24 PAs are replaced by 15 Port System Authorities (PSAs). In line with the rationale of the document, PSAs inherit the duties and the power of traditional PAs, with a broader geographical scope. Existing PAs, indeed, have been grouped into PSAs in accordance with historical background, political pressures, port characteristics and hinterland profile. For example, the three Ligurian ports were included in two different PSAs while three Apulian PAs formed a single PSA joining also a couple of minor ports (see Figure 4).

Figure 4. The new population of Port Authorities.

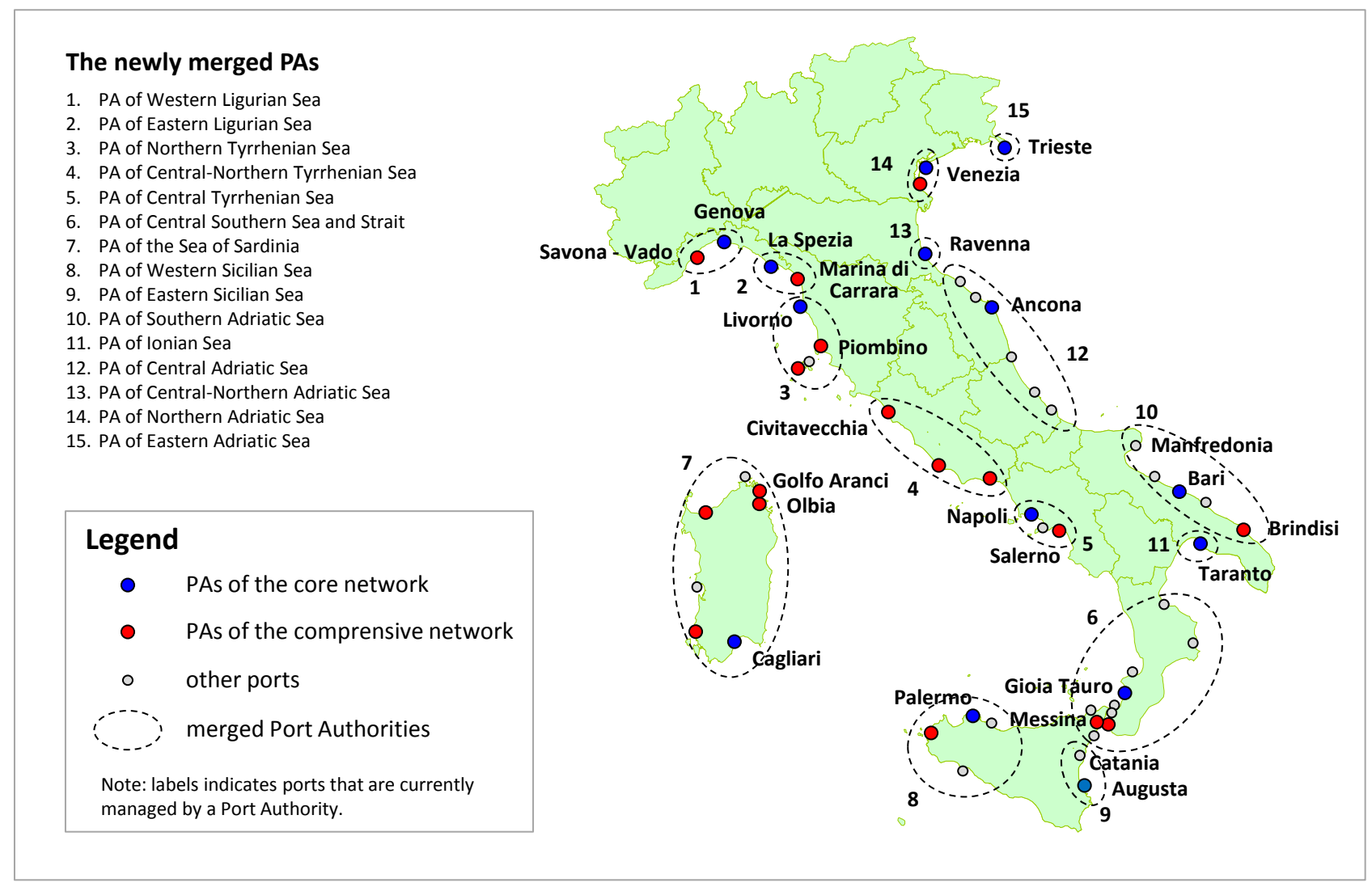

Source: author's own elaboration.

PSAs are expected to play a coordination role, while for each former PA, a special Port Directorate (PD) will be in charge of the current PA tasks and duties, after proposing the implementation of different actions to the President of the PSA it belongs to. As a consequence, while the introduction of a coordination mechanism (i.e. the establishment of PSAs) is predicted to bring to a 
rationalization of small ports, redundancies may originate from the presence of two diverse entities (i.e., PDs and PSAs), thus generating function overlap and reducing the positive effect of the new organization.

Although the establishment of PSAs is considered the major port reform breakthrough, two additional drivers are expected to impact on the forthcoming port organisation, i.e. the internal organisation of PSAs, and the management of the external relationships with the central government. Considering the former, although extant planning tools (i.e. master plan, TOP and concession agreements) will endure the reform, the new Authorities will be organised in a different way. In particular, the PD will hold direct responsibility of ports and, conversely, the Port Committee, representative of major port stakeholders categories, will lose decisional power in respect to the past, having only a consultative role. As concerns the relationships with the central government, PSAs' presidents will be appointed directly by the Ministry (while, in accordance to the old port law, it was selected by the Ministry among three experts suggested by the local public authorities) and a special department within the Ministry will be introduced. This new department is called to rationalize and coordinate investments and financial resources of different PSAs, as a whole.

This multilevel organization will create three layers of port strategic actions, with the Central level having a great influence on the financial aspect, the PSAs playing the key planning and coordination role, and the PDs managing local resources.

Therefore, although the aforementioned National Strategic Plan introduces substantial modifications to the current port governance settings, it does not dedicate similar efforts in proposing improvements for overtaking other critical port dimensions, such as marine services, labour pools, investments and concession agreements.

As said, the National Strategic Plan was the starting point of the political process. Once presented, it was first discussed with major port stakeholders (e.g. Assoporti, Confetra, terminal operators) and then the government representatives activated the legislative path. As ports, according to the Italian Constitutional law, are not an exclusive issue of the Central Government, one of the key steps of a port reform is the discussion with local governments (i.e. Regions). As a consequence, during the winter 2015-2016, the political discussion with local authorities led to several modifications to the original draft developed within the National Strategic Plan.

Substantial changes occurred given the local political pressure to preserve some PAs, or due to interand intra-regional conflicts concerning the establishment of PSAs. As a result, three additional PSAs have been introduced and the aggregation of two medium-sized ports (i.e. Savona and Salerno) with their neighbouring ports (i.e. Genoa and Naples) has been postponed. Due to the national and local political pressures, as well as the raise of multiple conflicts, a number of port-related issues are still neglected by the reform, including, among others, port labour regulation and concessions. In this perspective, the government has stated that additional special law and rules will be introduced after the conclusion of the ongoing discussion on the port reform, aiming at increase its legal consistency with "collateral" dimensions such as labour and concessions. 


\section{Looking ahead: A critical review}

Despite the reform has been inspired by fair principles such as rationalization and administrative simplification, some academics and practitioners (specifically, port stakeholders) questioned its suitability. A number of PA executives criticized the reform given the lack of managerial orientation and the low degree of independence ensured to PAs.

Overall, substantial institutional divergence emerged between the objectives set at governmental level and the claims emerging at regional / port level, during the different stages of the reform. In addition, or possibly as a result, an intrinsic (internal) incoherence exists between the National Strategic Plan elaborated by the Ministry and the reform draft called to redesign the port governance framework. The ambitious guidelines drawn by the plan, that aspires at enlarging Italian ports' hinterland and capturing additional cargo flows beyond the Alps, clearly fail to put suitable governance mechanisms in the hands of PAs and their managers. In this vein, the framing of the port reform into the national law restructuring the whole Public Administration closes the doors to any attempt of commercialization or corporatization of Pas/PSAs, that should remain public entities, with regulatory and authoritative functions, not entitled to achieve any economic objective.

In addition, the reform settles a rather "light" reform, and unveils fuzzy and weak contents. As stated, the restructuring of governance settings grounds on contradictory reform tools, which unveil internal inconsistency and drawbacks. Therefore, the entire reform framework offers inadequate or just partial replies to the most urgent critical issues affecting the extant institutional context.

By scrutinizing the entire reform process, it emerges the concrete risk of a growing institutional "divide" between the central government and local administrations (i.e. Regions). This is clearly demonstrated by the institutional "distance" between the contents and objectives imposed at national level and the changes requested at regional scale, that remain mostly unsatisfied. In other words, a gap persists between the intended reform sketched by the central government and the emergent reform claimed by local institutions and stakeholders. The former (intended reform) was settled by the Ministry of Transport and Infrastructure (and, more indirectly, also by the Prime Minister), conversely, the latter (emergent reform) originates from a multitude of actors embedded in diverse territories, such as PAs, regional administrations, municipalities, port users, trade associations, etc. The fragmentation and heterogeneity of local contexts constituted a weakness for bottom-up reform claims that, in many cases, lost momentum as individual stakeholder requests were isolated each other and therefore lacked the critical mass for contrasting the top-down reform design.

During the process of approval, emergent reform solutions have been submitted to central government through both informal and formal paths. Among informal options, "voice" is typically the most relevant for public institutions (such as local PAs) and port users. Nevertheless, this option has been substantially weakened as most PAs came under the control of government-appointed administrators that, obviously, could not exert any real voice against the reform "intended" at central level. Among the formal tools, the debate inside the permanent "State-Regions Committee" (political body created for discussing issues which fall under the competencies of both central and 
regional governments) became a relevant one. Nonetheless, in this reform process the approach of the Cabinet has been quite strict and the room for negotiation very narrow.

Given the above combined political behaviors, a progressive institutional divergence materialized between the reform pillars intended by the central government and the claims emerging at local level. Relatedly, Figure 5 unveils the institutional dimensions still at the core of the debate among institutions. At the systemic level, the reform fails to provide an effective hybridization of governance models, neglecting to recognize the diverse strategic relevance of ports. Probably, some steps forward have been done but, as a paradox, the Italian port system was more equilibrated before the 1994 Reform, when a handful of key ports enjoyed differentiated governance settings and special administrative regimes. The central government was resistant to the claims of differentiated governance solutions emerging in key port Regions and continues to pursue its reform design, regardless of clear international trends heading towards the hybridization of models (e.g., Germany, The Netherlands, Greece, France, etc.). In addition, the reform overcomplicates the institutional chain by adding a couple of new "layers" (four, overall) where decisions and lobbying effects can be generated. In each PSA, besides the main headquarters (headed by a President) there are some local administrative offices (with a local director) entitled to manage local facilities and stakeholder relations. Moreover, a national coordinating committee has been established at national level aiming at facilitating the dialogue between PSAs and the Ministry. This solution is quite unique and will probably increase the complexity of vertical relationships among institutions with legislative competences in port affairs (such as Municipality, Region, etc.). In this picture, decisional power has been dramatically shifted from the periphery to the core (centralization), weakening PSAs and local territories.

Figure 5. Risk of institutional divergence: intended and emergent reforming forces in relation to some key points on the agenda.

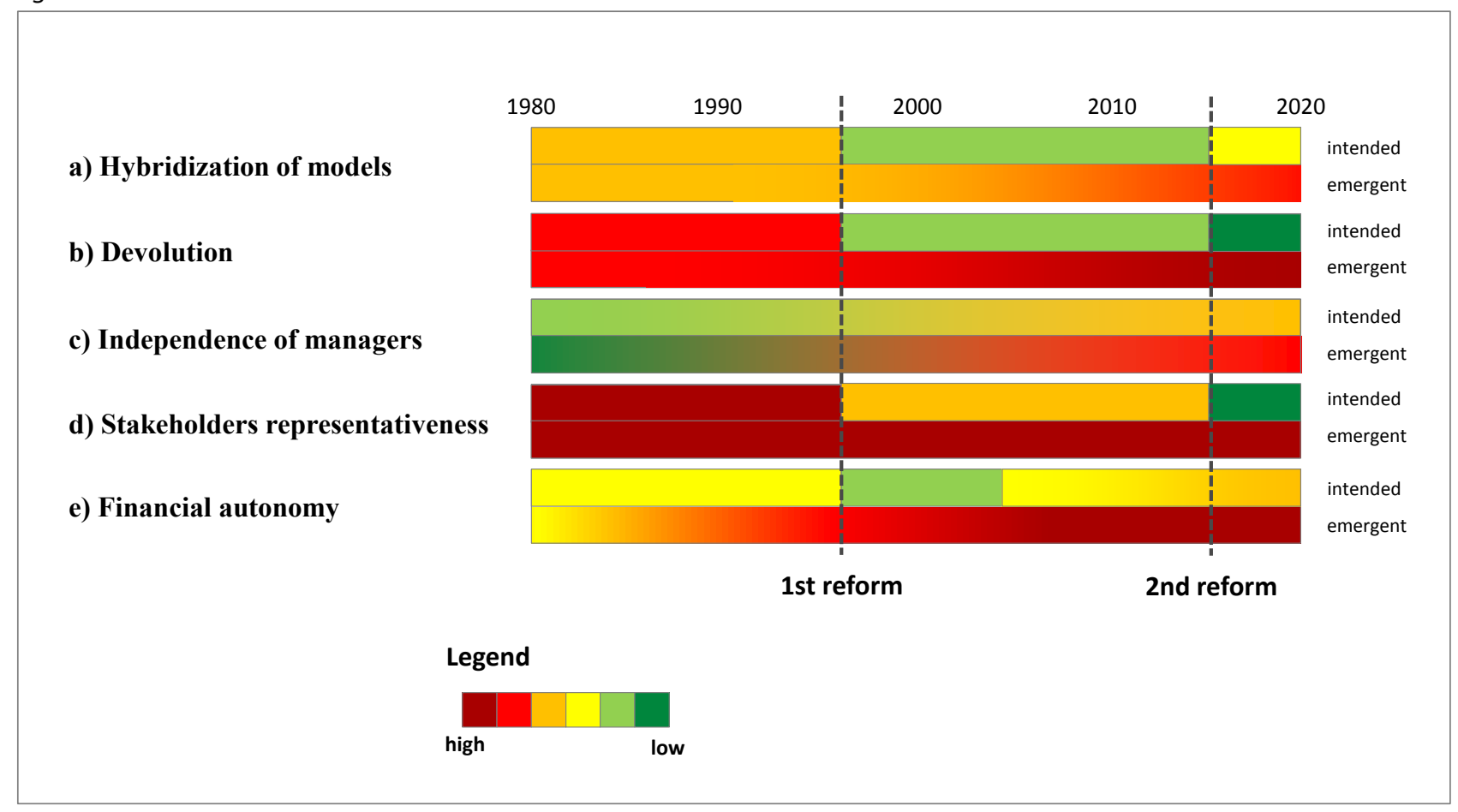

Source: authors' own elaboration. 
Instead of undertaking a process of devolution, the reform goes in the opposite direction, neglecting to hear emerging reform proposals (embeddedness) and to follow international trends (path dependence). Therefore, the reform design fails to create a "plastic" institutional framework capable to shape itself in relation to local market need.

Regarding the nature and functions of new PSAs, an important concern arises comparing the reform scheme imposed by the government and various local proposals. In essence, the reform encapsulates the PA within public administration bodies, forbidding to undertake any kind of business activity. This approach is not consistent with trends materializing in most important maritime nations where PAs pursue commercial objectives and also try to make profitable investments. This reform represents a lost opportunity to corporatize the biggest Italian PAs, as asked by some stakeholder categories. Only the corporatization of PAs would enable to appoint independent managers as port executives, instead of political representatives. This would probably stimulate operational efficiency and the setting of profit-driven objectives, thanks to the creation of more proactive PAs, capable to keep the pace with stakeholders' behaviors and expectations (Verhoeven and Vanoutrive, 2012).

Indeed, the political decision of maintaining the PA as a Public Administration entity restricts the possibility to undertake hinterland transportation strategies, as equity investments are still not allowed. Also marketing strategies are, de facto, not really possible as value-driven activities are forbidden. Another debated point was the degree of representativeness that should be ensured to local stakeholders inside port executive bodies. In this regard, the reform excludes stakeholders from executive functions, limiting their role to PA managers' supervision. According to many local claims, the role assigned to stakeholders is too weak and should be empowered. However, looking at other governance frameworks at international level, evidence brings mixed results. Some top ports like Rotterdam decided to exclude stakeholders from executive power whereas ports like Antwerp or Los Angeles still embark stakeholders in the boards of directors. Finally, financial autonomy probably is one of the most controversial issues. Basically, since 1994 PAs progressively increased their financial autonomy. In particular, in mid-2000s a number of regulatory actions enabled PAs to substantially increase their source of revenues. Nowadays autonomous revenues (mostly concessions fees and port dues) are largely enough for taking care of current expenses. Indeed, the critical point is constituted by long-term investments. So far, public transfers from central government are still a necessary ingredient for realizing investments both in leading and small/medium-sized ports. Contrary to the expectations of the large maritime regions (i.e., Liguria and Campania), the top-down reform process neglected to provide additional revenue flows to the most performing ports. Public transfers are still issued on a rather random basis, following supplydriven (and not demand-driven) logics biased by political pressures. Indeed, corporatization schemes would also extend the array of viable funding options for PAs. Relatedly, the introduction of amortization mechanisms should increase the personal commitment of managers, pushing towards efficiency ad self-financing options. Overall, financial autonomy is one of the most disappointing items of the entire reform. Also in this regard, local claims appear much more aligned to international trends rather than national solutions. 
Given the contradictory outcomes outlined above, the reform risks to generate substantial concerns in a long-term perspective (Figure 6).

Figure 6. Institutional forces and realized reform: the risk of a permanent institutional divergence

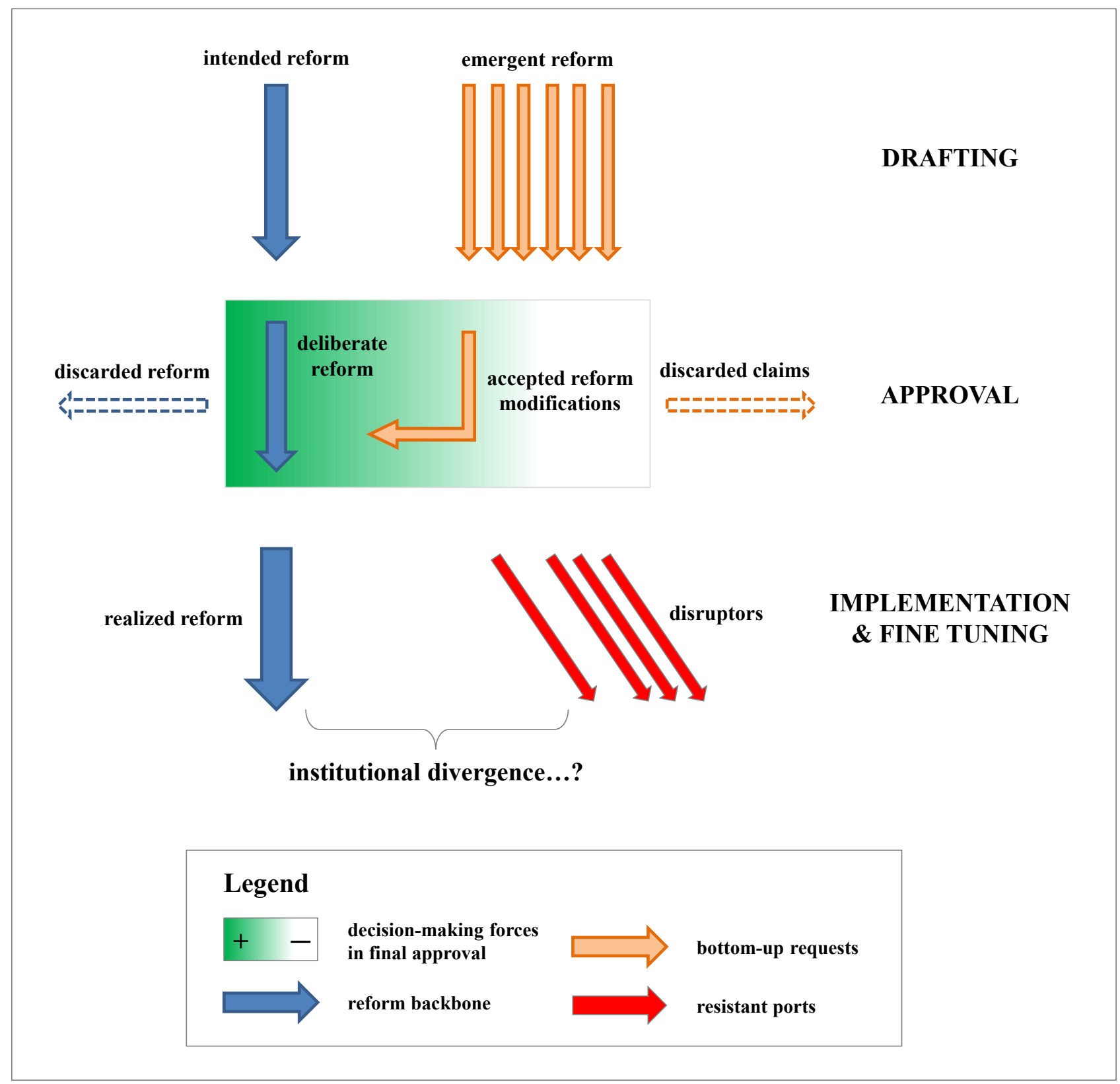

Source: authors' own elaboration.

The missing hybridization of models preconizes a growing institutional rift in the years to come between the actions performed at local level and the rules set by central government. This local versus national divergence has been initially feed in the drafting stage of the reform law. Regions and local stakeholders were almost excluded from the process both formally and informally. Later on, in a more advanced negotiation phase and during final approval, the fragmentation of local forces allowed the government to go ahead quickly and to limit the commitment of stakeholder to the minimum required (time compression process). Only a few amendments drafted by local 
institutions were accepted after negotiation and became part of the "realized reform". However, the more risky phase is the implementation process that can even last for some years. This phase might be characterized by severe conflicts because some disruptor ports could create obstacles to the concrete application of the reform in specific local contexts. Grounding on the taxonomy introduced by Debrie et al. (2013), we can expect that beside some follower ports, where the implementation of national legislation will take place easily because of the weak local embeddedness forces, other ports could act as path adaptor or path resistant ports. The formers might be characterized by some local minor adjustments on the national framework, generating institutional convergence but in the mid/long-term. The latter ones could be reasonably the major ports of the country that have been hindered by the national reform proposal. These ports will try to adopt alternative solutions for specific concerns not addressed satisfactorily by the reform design. In this case, therefore, local forces may generate conflicts which thwart and slow down the implementation of the top-down reform (i.e. lock-in effect). Embeddedness forces and local institutional inertia respect to governmental decree risk to postpone the implementation stage, by causing a deep institutional divergence. At this stage of the process (under reform implementation), risks are difficult to be evaluated. However, given the strong approach of the government heading towards centralization and the modest power of negotiation of local stakeholders during drafting and approval phases, it is possible to preconize a rather intense phase of implementation and finetuning where the arm-wresting between regional and national institutions will become fiercer.

\section{Concluding remarks}

The evaluation of port governance reform processes which have been occurring in many countries since the beginning of the century should take into consideration the embeddedness of ports in (multi-scale) institutional and economic contexts, as de-contextualization may cause rigid processes which fail to match the industry requirements and may generate institutional divergence. An approach based on the notions of intended and emerging strategies and of institutional plasticity can minimize the above mentioned risks. This paper applies precisely this analytical approach in focusing on the Italian port reform process, recently concluded after ten years since its beginning.

Indeed, a number of countries are experimenting hybrid forms of governance for capturing the needs and specificities of local port regions. The plasticity of such governance frameworks allows a fluid interaction and reciprocal feeding between central and local forces, and therefore constitutes a critical success factor of some maritime countries that become capable to offer an effective and adaptive institutional system. Conversely, an analysis of the Italian case unveils that the port reform process is still partially inadequate to capture and incorporate some urgent local requirements. The lack of a bottom-up perspective and of local adaptation, which historically have demonstrated to read into global challenges, may constitute a dangerous drawback of the extant port reform. The outcome of the reform process and the critical arguments developed in this study raise unforeseen managerial challenges for port executives. PA managers are called to deal with a very delicate process of reform implementation that contains itself a number of traps in the definition of new organizational settings and executive functions. Private managers, indeed, should be able to cope 
with an evolving administrative framework that, in some circumstances, could show institutional conflicts and blurred public-private interactions.

To a certain extent, a "glo-cal" paradox emerges as in given circumstances local actors appear capable to interpret global challenges more effectively than national institutions. The Italian reform fosters a re-centralization process instead, and seems to counter the worldwide corporatization trend. The entire draft reform seems to respond more to trends prevailing in national politics, instead than in international and local (the "glocal" paradigm!) economic contexts. Also, the effects of an ongoing profound constitutional reform may interact with the reform process, with most uncertain outcomes.

A gap results between intended and emerged reform trends in all the key drivers of port competitiveness: namely in financial autonomy for long run infrastructural investment, but partly also in stakeholders' representativeness, independence of managers, hybridization of models and, clearly, devolution process. In all these topics the reform outlines a myopic institutional design that fails to set up a dialogue with local territories. The reluctance of the central government (national embeddedness) respect to global trends that ask for lean and adaptive PA organizations crashes against local forces that seem more ready to address international challenges.

The reason for that is - most likely - that the "local" claims of top ports and port communities are more in tune with the international trends, so that the path dependence is tightly related to the (local) embeddedness. But the national reform process appears to be ruled by political negotiation, which gives more space to other goals and other players. Therefore, the "apparently" nationallydriven issues are mostly the collection of local-driven political pressures.

If this is true, what should be accurately investigated is the link between the evolution of port governance models, either top-down (path dependence) or bottom-up (embeddedness), and the institutional capacity needed for developing and implementing/enforcing the reform process. A process that should be ideally capable to match the innovation required by path leader/pioneer ports, in order to maximize path followers and path adaptors and minimize path resistants. The "example" of the Italian reform process may provide suggestions for revising the theoretical framework in order to improve reform processes in the port sector worldwide.

\section{References}

Ansoff, I., 1965. Corporate Strategy: An Analytic Approach to Business Policy for Growth and Expansion. McGraw-Hill, New York, NY, p. 241.

Brooks, M.R., 2007. Port devolution and governance in Canada. In: Brooks, M.R., Cullinane, K. (Eds.), Devolution, Port Governance and Port Performance, Research in Transportation Economics, vol. 17, no. 1. Elsevier, London, UK, pp. 237-257.

Brooks, M.R., Pallis, A.A., 2008. Assessing port governance models: process and performance components. Maritime Policy \& Management 35 (4), 411-432. 
Caballini, C., Carpaneto, L., Parola, F., 2009. Italian port authorities approaching the post-reform: the Ligurian case. In: Notteboom, T., de Langen, P., Ducruet, C. (Eds.), Ports in Proximity: Competition and Coordination Among Adjacent Seaports. Ashgate, Aldershot, UK, pp. 191-208.

Carbone S.M. and Munari F. (2006). La disciplina dei porti tra diritto comunitario e diritto interno, Giuffré, Milan.

Consulta Nazionale per l'Autotrasporto e la Logistica (2011). National Logistics Plan 2011- 2020. Rome.

Costa P. and Casagrande M. (2011). Dalla concorrenza nei porti alla concorrenza tra i porti, Marsillo Editori, Venice.

de Langen, P. W. (2004a). The performance of seaport clusters. Rotterdam: ERIM, Erasmus Research Institute of Management (PhD dissertation).

de Langen, P. W. (2004b). Governance in seaport clusters. Maritime Economics \& Logistics, 6(2), 141-156.

de Langen P.W., Heij C. (2014). Corporatisation and performance: a literature review and an analysis of the performance effects of the corporatisation of port of Rotterdam authority, Transport Reviews, 34, pp. 396-414.

Debrie, J., Lavaud-Letilleul, V., Parola, F. (2013). Shaping port governance: the territorial trajectories of reform. Journal of Transport Geography, 27, 56-65.

Dobry, M., 2000. Les voies incertaines de la transitologie: choix stratégiques, séquences historiques, bifurcations et processus de path dependence". Revue française de science politique 50 (4-5), 585614.

Dooms, M., van der Lugt, L., \& de Langen, P. W. (2013). International strategies of port authorities: The case of the Port of Rotterdam Authority. Research in Transportation Business \& Management, $8,148-157$.

Everett S. and Robinson R. (2007). Port Reform: The Australian Experience. Research in Transportation Economics, 17, pp. 259-284.

Ferrari C. and Musso E. (2011). Italian ports: towards a new governance?, Maritime Policy \& Management, 38, pp. 335-346.

Ferrari, C., Parola, F., Tei, A. (2015a). Governance models and port concessions in Europe: Commonalities, critical issues and policy perspectives. Transport Policy, 41, 60-67.

Ferrari, C., Tei., A., Merk, O. (2015b). The Governance and Regulation of Ports - The Case of Italy. OECD/ITF Discussion Paper 2015-1.

Fremont, A., Lavaud-Letilleul, V., 2009. Rethinking proximity: new opportunities for port development. The case of Dunkirk. In: Notteboom, T., de Langen, P., Ducruet, C. (Eds.), Ports in Proximity: Competition and Coordination Among Adjacent Seaports. Ashgate, Aldershot, UK, pp. 175-189. 
Gertler, M.S., 2001. Best practice? Geography, learning and the institutional limits to strong convergence. Journal of Economic Geography 1, 5-26.

Granovetter, M., 1985. Economic action and social structure: the problem of embeddedness. American Journal of Sociology 91 (3), 481-510.

Hall, P.V., 2003. Regional institutional convergence? Reflections from the Baltimore Waterfront. Economic Geography 79, 347-363.

Hall, P. V., \& Jacobs, W. (2010). Shifting proximities: The maritime ports sector in an era of global supply chains. Regional Studies, 44(9), 1103-1115.

Hess, M., 2004. Spatial relationships? Towards a reconceptualization of embeddedness. Progress in Human Geography 28 (2), 165-186.

Mackinnon, D., Cumbers, A., Pike, A., Birch, K., Mcmaster, R., 2009. Evolution in economic geography: institutions, political economy and adaptation. Economic Geography 85 (2), 129-150.

Marchese U., Musso E. and Ferrari C. (1998). The role for ports in intermodal transports and global competition: a survey of Italian container terminals, in H. Meersman, E. Van de Voorde and W. Winkelmans (eds.), Transport Modes and Systems. Vol. 1, Amsterdam, Pergamon, pp. 141-154, ISBN: 0080435904.

Martin, R., 2010. Roepke lecture in economic geography: rethinking regional path dependence: beyond the lock-in to evolution. Economic Geography 86 (1), 1-27.

Martin, R., Sunley, P., 2006. Path dependence and regional economic evolution. Journal of Economic Geography 6, 603-618.

Mintzberg, H., Waters, J.A., 1985. Of strategies, deliberate and emergent. Strategic Management Journal 6, 257-272.

MIT - Italian Ministry of Transport (2015). Iniziativa di studio sulla portualita' italiana, Department For Planning and Coordination of the Economic Policy, Rome.

$\mathrm{Ng}$, A., Pallis, A., 2010. Port governance reforms in diversified institutional frameworks; generic solutions, implementation asymmetries. Environment and Planning A 42, 2147-2167.

Notteboom T. and Rodrigue J. P. (2008). Containerization, box logistics and global supply chains: The integration of ports and liner shipping networks, Maritime Economics and Logistic, 10, pp. 152-174.

Notteboom, T., De Langen, P., Jacobs, W. (2013). Institutional plasticity and path dependence in seaports: interactions between institutions, port governance reforms and port authority routines. Journal of Transport Geography, 27, 26-35.

Notteboom, T., Parola, F., Satta, G., Penco, L. (2015). Disclosure as a tool in stakeholder relations management: a longitudinal study on the Port of Rotterdam. International Journal of Logistics Research and Applications, 18(3), 228-250.

Olivier, D., Slack, B., 2006. Rethinking the port. Environment and Planning A 38, 1409-1427. 
Parola F., Tei A., Ferrari C. (2012). Managing port concessions: evidence from Italy. Maritime Policy \& Management, 39, pp. 45-61.

Parola, F., and Maugeri, S. (2013). Origin and taxonomy of conflicts in seaports: Towards a research agenda. Research in Transportation Business \& Management, 8, 114-122.

Parola, F., Satta, G., Penco, L., Profumo, G. (2013). Emerging Port Authority communication strategies: Assessing the determinants of disclosure in the annual report. Research in Transportation Business \& Management, 8, 134-147.

Sánchez, R.J., Wilmsmeier, G., 2006. In: Brooks, M.R., Cullinane, K. (Eds.), The River Plate Basin - A Comparison of Port Devolution Processes on the East Coast of South America. Devolution, Port Governance and Port Performance, Research in Transportation Economics, vol. 17, no. 1. Elsevier, London, UK, pp. 185-205.

Slack, B., Gouvernal, E., \& Debrie, J. (2009). Proximity and port governance. In T. E. Notteboom, P. De Langen, \& C. Ducruet (Eds.), Ports in proximity: Competition and coordination among adjacent seaports (pp. 75-86). Aldershot: Ashgate.

Storper, M., 1997. The Regional World: Territorial Development in a Global Economy. The Guildford Press, New York.

Strambach, S., 2010. Path dependence, path plasticity-the co-evolution of institutions and innovation. The German business software industry. In: Boschma, R.A., Martin, R. (Eds.), Handbook for Evolutionary Economic Geography. Edward Elgar, Cheltenham, pp. 406-431.

Valleri M.A., Lamonarca M. and Papa P. (2006). Port governance in Italy. Research in Transportation Economics, 17, pp. 139-153.

Van den Berg, R., de Langen, P. W. (2011). Hinterland strategies of port authorities: A case study of the port of Barcelona. Research in Transportation Economics, 33(1), 6-14.

van der Lugt, L., Dooms, M., and Parola, F. (2013). Strategy making by hybrid organizations: The case of the port authority. Research in Transportation Business \& Management, 8, 103-113.

Verhoeven, P., Vanoutrive, T. (2012). A quantitative analysis of European port governance. Maritime Economics \& Logistics, 14(2), 178-203.

Verhoeven, P., 2010. A review of port authority functions: towards a renaissance? Maritime Policy \& Management 37 (3), 247-270.

Wang, J.J., Ng, A.K.-Y., Olivier, D., 2004. Port governance in China: a review of policies in an era of internationalizing port management practices. Transport Policy 11, 237-250.

World Bank, 2007. Port Reform Toolkit, $2^{\text {nd }}$ edition, Washington DC, USA. 